\title{
Economics of sale weight, herd size, supplementation, and seasonal factors
}

\author{
RUSSELL TRONSTAD AND TRENT TEEGERSTROM
}

Authors are Associate Professor and Extension Specialist, and Research Specialist, Department of Agricultural and Resource Economics, College of Agriculture and Life Sciences, The University of Arizona, Tucson, Ariz. 85721-0023.

\section{Abstract}

A growth function for range calves is estimated using a polynomial function of calf age that accounts for weather variation, sex, prior calf weights relative to a norm, and a compensatory gain factor. Data on rainfall plus calf weights at birth and when calves were roughly $3,8,12$, and 20 months of age are used to estimate the growth function. This function is then used to determine the economic trade-off between herd size and calf sale weights, for both spring and fall sale dates. In addition, the profitability of feeding supplement is evaluated by increasing the rate of gain beyond that projected by the the polynomial age growth function for southeast and central Arizona grazing environments when forage and nutrients are limited. Using prices from 1980 to 1998 , results indicate that the most profitable herd mix, sale date, and feeding protocol for the southeast Arizona region is $204 \mathrm{~kg}$ calves with no supplemental feeding and sales occurring in May. Supplemental feeding and sales occurring at $250 \mathrm{~kg} \mathrm{head}^{-1}$ in May is the most profitable herd mix for the central Arizona region. More favorable average daily gain rates for May sales from the central versus southeast is why supplemental feeding is marginally better for the central region than feeding no supplement.

Key Words: optimal calf sale weight, livestock supplementation effects, livestock marketing, polynomial age growth function, rainfall

The trade-off between sale weight and timing of sales is complicated by seasonal forage and price conditions along with variation in the price spread between light and heavy calves. Generally, lighter calves sell for a higher price per unit of weight than heavier calves and calf prices in the spring are greater than in the fall, but exceptions to these generalities occur. In addition, variability in seasonal rainfall and the ability to feed supplement complicates analyzing trade-offs between rates of gain, sale weight, herd size, and the timing of calf sales.

Some ranches have adopted a rather rigid selling practice for their calves to take advantage of seasonal forage availability and aggregate numbers for a given sale to attract more buyers. For example, ranchers in the central region of Arizona typically sell calves in the spring while southeast Arizona ranchers generally sell in the fall. Both regions sell mainly according to the time of year, irrespective of the weight of their calves, and very few feed substantial supplements. Because Arizona ranchers often question the economic trade-offs between calf sale weights, herd size, rates of gain and feeding supplement, and a spring versus fall sale

Manuscript accepted 14 Oct. 02.

\section{Resumen}

Se estimó una función de crecimiento para becerros en pastizales usando una función polinomial de la edad del becerro que toma en cuenta la variación de clima, el sexo, los pesos de becerro relativos a la norma y un factor de ganancia compensatoria. Datos de precipitación, del peso de los becerros al nacimiento y del peso cuando tenían aproximadamente $3,8,12$ y 20 meses se usaron para estimar la función de crecimiento. Luego esta función se uso para determinar los sacrificios económicos entre el tamaño del hato y los pesos de venta de los becerros, tanto para fechas de venta de primavera como de verano. Adicionalmente, se evaluó la rentabilidad de suplementar para incrementar la tasa de ganancia más alla de lo proyectado por la función polinomial de edad de crecimiento para ambientes de apacentamiento del sudeste y la región central de Arizona cuando el forraje y los nutrientes son limitantes. Usando precios de 1980 a 1998, los resultados indican que la mezcla de hato, fecha de venta y protocolo de alimentación más rentables para la región sudeste de Arizona es becerros de $204 \mathrm{~kg}$ sin suplementación y las ventas realizadas en Mayo. La alimentación suplementaria y las ventas en Mayo con pesos de $250 \mathrm{~kg}^{\text {cabeza }}{ }^{-1}$ es la mezcla de hato mas rentable para la región central de Arizona. Las tasas promedio de ganancia diaria de peso mas favorables en Mayo de la región central versus la región sudeste es la razón por la que la alimentación suplementaria es marginalmente mejor para la región central que el no suplementar.

date, the primary objective of this analysis was to address these issues. More specifically, the profitability of an Animal Unit (AU) grazing resource is quantified with and without supplemental feeding under the different sale weights of either 159, 204, 250,295 , or $340 \mathrm{~kg} \mathrm{head}^{-1}$ for May and November sale dates from 2 different Arizona regions. In addition, the economic impact of a fertility increase in conjunction with supplemental feeding and the profitability of heavier calf weights during "extra grass" years are evaluated.

Quantifying the future rate of gain for a calf kept on the ranch is a critical element for evaluating the profitability of different marketing dates. Selling calves at a heavier weight generally comes with an opportunity cost of reducing the number of cows that can be maintained on the ranch, thus also reducing the number of calves that can be sold. Several studies have looked at animal performance under different range conditions with a production focus and little economic analysis (e.g., Clayton et al. 1983, Fox and Black 1977, Tess and Kolstad 2000). Notable exceptions are Van Tassell et al. (1987) and Lambert (1989). Van Tassell et al. (1987) quantified variations in calf weights from different 
managerial, biological, and weather variables. Six separate models were used to estimate calf weights at 6 different ages. The model developed herein differs since it estimates calf weight as a continuous function of age from birth to 20 months of age. Variation in birth dates and subsequent single-day weighing dates for all calves after birth allows for calf weights to be estimated as a continuous function of age.

Lambert (1989) used a discrete stochastic programming model to evaluate the retention of fall-weaned calves and their optimal rate of gain under different states of nature and price expectations. The purchase of additional winter feed rations was required to retain calves and maintain the size of the cow herd. Given that feeding hay as an energy source to southwestern range cows is quite costly and generally kept to a minimum, this study evaluates the cost of heavier calf weights as a tradeoff with reduced cow numbers rather than as additional feeds purchased. This framework identifies the best herd mix for the fixed range resource. Supplemental feeding is considered, but retaining calves to reach heavier weights still does not occur without some reduction in cow numbers. This analysis also evaluates seasonal market and production factors associated with calf and cull cow sales occurring in either the spring (mid-May) or fall (midNovember.)

\section{Materials and Methods}

Calf weight data was collected from the registered Hereford herd of the San Carlos Apache Tribal Ranch, Arsenic Tubs, Ariz. (N33 $\left.20^{\circ} 30^{\prime \prime}, \mathrm{W} 109^{\circ} 48^{\prime} 46^{\prime \prime}\right)$ for the 8 years of $1980,1981,1983$ to 1986,1988 , and 1989. These years were the most complete and current we could find for calf weights from birth to 20 months of age. A birth date and calf weight at birth was recorded for each calf. In addition, weights were taken when the entire calf crop was at an average age of roughly $3,8,12$, and 20 months of age. Weight and animal combinations are such that we have 1,368 calves and 5,862 unique calf weights. There was not a complete set of weight data for all calves. Most of the missing weights were associated with 3-month weights. Different calving dates provide age variation around each weighing date so that calf weight was estimated as a continuous function with respect to age.
More formally, calf $i$ 's weight $\left(\mathrm{kg} \mathrm{head}^{-1}\right)$ at the $j$ th weighing $\left(\mathrm{WT}_{i, j}, j=1,2,3,4\right.$, and 5 , and corresponds to weights taken at birth and roughly $3,8,12$, and 20 months of age) was estimated as

$$
\begin{aligned}
& W T_{i, j}=G F R S_{i, j}+\left(D _ { j } \delta _ { w j } \left(W T_{i, j-1}-\right.\right. \\
& \left.\left.\operatorname{GFRS}_{i, j-1}\right)\right)_{j \geq 2}+\left(D_{j} \delta_{C G j} C G_{i, j}\right)_{j=5}+\varepsilon_{i, j} \\
& G F R S_{i, j}=\left(\sum_{a=0}^{8} \beta_{i} A g e_{i, j}^{a}+\left(D_{j} \delta_{r j} \operatorname{Rain}_{i, j}^{j-1 t o j}\right)_{j \geq 3}\right) \\
& \left(1-D H_{i} \delta_{h}\right), \text { and } \\
& C G_{i, 5}=\left[\left(W T_{i, 4}-W T_{i, 3}\right)-\sum_{a=0}^{8} \beta_{i}\left(A g e_{i, 4}^{a}-\right.\right. \\
& \left.\left.-A g e_{i, 3}^{a}\right)\right]\left[1-D H_{i} \delta_{h}\right] .
\end{aligned}
$$

The term $G F R S_{i, j}$ corresponds to calf weight $\left(\mathrm{kg} \mathrm{head}^{-1}\right)$ estimated as an $8^{\text {th }}$ order polynomial growth function of calf age in months $\left(A g e_{i, j}\right)$ plus a rainfall component ${ }^{1}$ $\left(\operatorname{Rain}_{i, j}^{j}{ }_{i, j}^{l t j}\right)$, and this weight is adjusted lower by a constant percentage $\left(\delta_{h}\right)$ for heifers. The term $\operatorname{Rain}_{i, j}^{j}{ }_{i, j}$ is the rainfall (cm) accumulated for the months between the prior and current weighing periods $(j-1$ to $j$ for $j \geq 3$ ) minus the 30-year-average rainfall for these same months, as reported by the Western Regional Climate Center (1961-1998) for the San Carlos Reservoir. The polynomial growth function has flexibility to allow for the dip in calf weight that occurs from weaning and seasonal forage availability. Rainfall effects were not considered for birth and 3-month weights since cows will generally pull down their body condition to provide milk for a young suckling calf if rainfall and forage has been poor (Sprinkle 2000). Similarly, compensatory gains were not considered for weigh dates other than the 20-month weighing since a calf obtains most of its nutrients from the cow between birth and the 3-month weighing.

Compensatory gain at the 20 -month weighing or $C G_{i, 5}$ is accounted for by using the difference between the actual weight change from the $12^{\text {th }}$ and $8^{\text {th }}$ month weighings versus the weight change expected from the polynomial growth function of calf age adjusted for

\footnotetext{
${ }^{\mathrm{I}}$ The $\mathrm{i}$ subscript is maintained for the rainfall variable to denote variation in rainfall from 1 year to the next, even though rainfall is the same for all calves within a given year.
}

sex differences. How a calf's actual weight compares to its norm based on age, sex, and rainfall at its previous weigh date (i.e., $W T_{i, j-1}-G F R S_{i, j-1}$ ) identifies calves that are consistently above or below their projected norm, whereas $C G_{i, 5}$ accounts for the unusual or non-consistent weight patterns. For example, a calf that was above the polynomial growth curve after accounting for sex differences at its 8month weighing but below this curve at its 12-month weighing can realize an extra or compensatory weight gain at its 20-month weighing through $C G_{i, 5}$.

The dummy variable $D_{j}$ equals 1 at the $j$ th weighing; otherwise, its value equals 0 . Similarly, $D H_{i}$ equals 1 or 0 if the $i$ th calf is a heifer or steer. $\varepsilon_{i, j}$ is a normally distributed error term with mean 0 and variance $\sigma^{2}$. Parameters estimated include an $8^{\text {th }}$ order polynomial function of age that describes a growth path for steers from birth to 20 months of age $\left(\beta_{0}, \ldots, \beta_{8}\right)$, coefficients that quantify rainfall effects on 8-, $12-$, and 20-month weighings $\left(\delta_{r 3}, \delta_{r 4}, \delta_{r 5}\right)$, values that describe how actual calf weights relative to their norm at prior weighings impact calf weights $\left(\delta_{w 3}, \delta_{w 4}, \delta_{w 5}\right)$, compensatory gain at the 20 -month weighing $\left(\delta_{C G 5}\right)$, and the percentage weight discount for heifers relative to steers $\left(\delta_{h}\right)$. Equation (1) was estimated using the least squares maximum likelihood procedure in TSPTM $\mathrm{v} 4.5$ (1999).

To gain insights into the trade-off between different sale weights and dates, real profits in constant 1999 dollars for 2 different ranching regions were simulated from 1980 through 1998 using either midMay or mid-November sale dates for steer calves that weighed either 159, 204, 250, 295 , or $340 \mathrm{~kg} \mathrm{head}^{-1}$. These weights correspond to the median of Cattle-Fax's sale weight categories so that $159 \mathrm{~kg}^{\text {head }}{ }^{-1}$ refers to sale prices within the weight range of 136 to $181 \mathrm{~kg}^{-1}$ head $^{-1}$ (i.e., 300 to $400 \mathrm{lb} \mathrm{head}^{-1}$ ) and similarly for the heavier sale weights. The 2 regions examined have distinct seasonal forage differences. The southeast region of Arizona is dependent upon the summer monsoon rains for warm season grass production, while central Arizona is more dependent upon winter rains for its production of cool season grasses and legumes such as jojoba (Simmondsia chinensis).

Table 1 shows the average daily gains estimated for different sale weights and dates by region plus the equivalent cow numbers that can be maintained for each scenario. Rates of gain for the 2 regions were set up to mirror each other with the 
Table 1. ADG (kg day $\left.{ }^{-1}\right)$ and equivalent cow numbers ${ }^{\mathrm{a}}$.

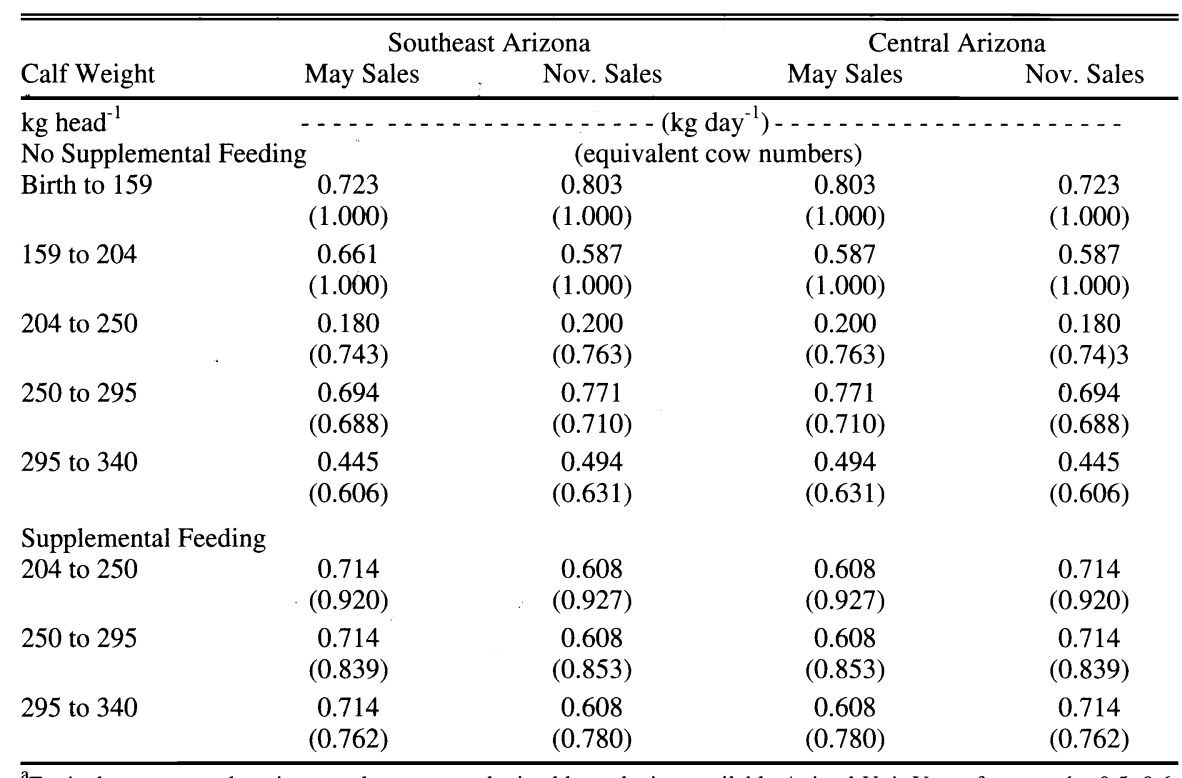

${ }^{\mathrm{a}}$ Equivalent cow numbers in parentheses were obtained by reducing available Animal Unit Years for cows by $0.5,0.6$, and 0.7 for the number of days it took calves that would be sold to go from 204 to 250,250 to 295 , and 295 to $340 \mathrm{~kg}$ head $^{-1}$, respectively. No distinction was made for weights less than 204 since these calves always reached their weight before 8 months of age, within the normal bounds of a one-year breeding and calving cycle.

most favorable gains occurring prior to November and May sales for the southeast and central regions. The most favorable forage conditions under supplementation assume a growth rate of $0.803 \mathrm{~kg} \mathrm{day}^{-1}$ for weights from birth to $159 \mathrm{~kg}$ and $0.794 \mathrm{~kg}$ day $^{-1}$ for weights from 204 to $340 \mathrm{~kg} \mathrm{head}^{-1}$. These rates of gain were reduced by $10 \%$ when forage is less abundant in each region prior to the animal's sale date. These growth rate assumptions and the $10 \%$ reduction applied when forage is less abundant were derived from conversations with University of Arizona colleagues and Arizona ranchers. To calculate the cows that could be supported on an Animal Unit Year (AUY) of forage, reductions of 0.5 , 0.6 , and 0.7 AUYs were charged for the number of days it took calves to go from 204 to 250,250 to 295 , and 295 to 340 $\mathrm{kgs}$, respectively. For example if it took 180 days for a calf to go from $204 \mathrm{~kg}$ to $250 \mathrm{~kg}$, the AUY reduction would be $0.5^{*}(180 / 365)$, where 0.5 is the assumed Animal Unit equivalency for this average calf weight. The AUY reduction for producing calves heavier than $204 \mathrm{~kg}^{\text {head }}{ }^{-1}$ has the effect of reducing total cow numbers and thereby reducing the number of calves available for sale. No opportunity cost of fewer cows is added when going from 159 to $204 \mathrm{~kg}$ sale weights since 204 $\mathrm{kg}$ calves are weaned at about 7 months of age, which allows ample time for cows to breed back in a year-round calving system.

Birth dates and supplement require- meal and cottonseed feed costs for the quarter fed as reported by U.S. Department of Agriculture, Agricultural Prices (1980-1998). Because some ranchers may be able to obtain more of a wholesale than retail price for supplement, we did not charge additional labor or fuel expenses for distributing supplement to the cow herd. However, the distribution costs for supplement may be very important, depending on the terrain of the ranch.

Another expense item that varied with different sale date and weight options was the opportunity cost of sale. That is, calves sold at $204 \mathrm{~kg}$ could have been sold at 159 $\mathrm{kg}$ and so forth. The opportunity cost of funds was charged at a real annual interest rate of $4 \%$. All other cost items except for grazing expenses were obtained from Economic Research Service's cow-calf production costs for the West (USDA 1982-1998). Cash grazing costs were calculated using the grazing fees and accompanying percentages of grazing land in Arizona owned by the State (33\%), Bureau of Land Management (17\%), Forest Service $(40 \%)$, or Private entity (9\%) as reported in Mayes and Archer (1982). Common variable and fixed cash expenses for all sale weight and date combinations are available in Tronstad et al. (2001). Gao (1996) also provides more detail about the cost items incorporated.

Cull cows were assumed to weigh 454 $\mathrm{kg} \mathrm{head}^{-1}$, irrespective of the herd's mix or production protocol. In addition, a calf crop percentage of $80 \%$ per exposed cow, calf death loss after birth of $2.5 \%$, and a culling percentage of $16 \%$ with a $4 \%$ annual death loss for cows was applied to all scenarios. The calf crop percentage of $80 \%$ per exposed cow falls within the range of values given in Teegerstrom and Tronstad (2000). Calf and cow death loss-

Table 2. Supplement requirements and calculated birth dates by sale date, sale weight, and location.

\begin{tabular}{|c|c|c|c|c|}
\hline \multicolumn{2}{|c|}{ Calving Date } & \multirow[b]{3}{*}{ Sale Weight } & \multirow{2}{*}{\multicolumn{2}{|c|}{$\begin{array}{c}\text { Supplement Required } \\
\text { 50:50 Corn \& Cottonseed Meal Ration }\end{array}$}} \\
\hline SE AZ & Central AZ & & & \\
\hline May Sales & Nov. Sales & & Calf & Calf-Cow \\
\hline & & $\left(\mathrm{kg} \mathrm{head}^{-1}\right)$ & $\left(\mathrm{kg} \mathrm{head}^{-1}\right)$ & $\left(\mathrm{kg} \mathrm{pair}^{-1}\right)$ \\
\hline 27 Nov. & 30 May & 159 & - & - \\
\hline 21 Sept. & 24 Mar. & 204 & - & - \\
\hline 19 July & 19 Jan. & 250 & 92 & 0 \\
\hline 17 May & 17 Nov. & 295 & 113 & 23 \\
\hline 14 Mar. & 14 Sept. & 340 & 136 & 45 \\
\hline Nov. Sales & May Sales & & & \\
\hline 16 June & 14 Dec. & 159 & - & - \\
\hline 16 April & 14 Oct. & 204 & - & - \\
\hline 18 Feb. & 18 Aug. & 250 & 0 & 45 \\
\hline 23 Dec. & 22 June & 295 & 0 & 92 \\
\hline 27 Oct. & 26 April & 340 & 0 & 136 \\
\hline
\end{tabular}

Note: Expert opinion was used to determine the supplement requirements needed to attain the ADG rates described in Table 1. 
Table 3. Range calf growth model and corresponding parameter estimates.

\begin{tabular}{|c|c|c|c|c|}
\hline Variables & Description & $\begin{array}{l}\text { sponding } \\
\text { ameters }\end{array}$ & $\begin{array}{l}\text { Parameter } \\
\text { Estimates } \\
\end{array}$ & t-values \\
\hline Constant & $\beta_{0}$ equals estimated birth weight & $\beta_{0}$ & 37.143 & 52.277 \\
\hline$A g e_{i, j}$ & $\left(\mathrm{~kg} \mathrm{head}^{-1}\right) . A g e_{i, j}$ indicates age of & $\beta_{1}$ & 96.924 & 13.246 \\
\hline$A g e_{i, j}^{2}$ & calf $i$ in months at the $j^{\text {th }}$ weighing & $\beta_{2}$ & -65.850 & -9.509 \\
\hline$A g e_{i, j}^{3}$ & for each of the corresponding & $\beta_{3}$ & 22.565 & 9.384 \\
\hline$A g e_{i, j}^{4}$ & $8^{\text {th }}$ order polynomial terms. & $\beta_{4}$ & -3.806 & -9.106 \\
\hline$A g e_{i, j}^{5}$ & Polynomial order associated with the age & $\beta_{5}$ & 0.345 & 8.569 \\
\hline$A g e_{i, j}^{6}$ & growth function was determined by applying & $\beta_{6}$ & $-0.172 \mathrm{E}-01$ & -7.890 \\
\hline$A g e_{i, j}^{7}$ & the Schwartz (1978) criteria of estimating & $\beta_{7}$ & $0.446 \mathrm{E}-03$ & 7.169 \\
\hline$A g e_{i, j}^{8}$ & $W T_{i, j}$ as a function of $\sum_{a=0}^{8} \beta_{i} A g e_{i, j}^{a}$ & $\beta_{8}$ & $-0.470 \mathrm{E}-05$ & -6.467 \\
\hline $\mathrm{DH}_{i}$ & Dummy variable that is 1 if heifer and 0 if steer. & $\delta_{h}$ & $-0.497 \mathrm{E}-01$ & -10.344 \\
\hline$\left(W T_{i, 1}-G F R S_{i, 1}\right)$ & Impact of the difference in animal $i$ 's weight at & $\delta_{w 2}$ & 0.534 & 2.120 \\
\hline$\left(W T_{i, 2}-G F R S_{i, 2}\right)$ & their prior weighing versus that expected by & $\delta_{w 3}$ & $0.274 \mathrm{E}-01$ & 1.839 \\
\hline$\left(W T_{i, 3}-G F R S_{i, 3}\right)$ & $G F R S_{i, j-1}$ at the $j^{\text {th }}$ weighing $(j=2,3,4$, and 5 & $\delta_{w 4}$ & 0.406 & 28.269 \\
\hline$\left(W T_{i, 4}-G F R S_{i, 4}\right)$ & $\begin{array}{l}\text { or the } 3,8,12 \text {, and } 20 \text {-month weighings, } \\
\text { respectively.) }\end{array}$ & $\delta_{w 5}$ & 0.763 & 35.872 \\
\hline$C G_{i, 20}$ & $\begin{array}{l}\text { Compensatory gain effect at the } \\
20 \text {-month weighing for animal } i \text {. }\end{array}$ & $\delta_{C G}$ & $-0.497 \mathrm{E}-01$ & -5.868 \\
\hline $\operatorname{Rain}_{i, 3}^{2103}$ & Centimeters of rainfall from the $j-1$ to $j$ month & $\delta_{r 3}$ & 2.001 & 17.120 \\
\hline $\operatorname{Rain}_{i, 4}^{3304}$ & weighing in a given year less the 30 -year-average & $\delta_{r 4}$ & 0.727 & 11.378 \\
\hline $\operatorname{Rain}_{i, 5}^{4 t 05}$ & rainfall for these same months $(j=3,4$, and 5$)$. & $\delta_{r} 5$ & $0.614 \mathrm{E}-01$ & 0.375 \\
\hline
\end{tabular}

$D_{j}$

Dummy variable that is 1 if it is the $j$ th weighing or 0 otherwise.

Notes: Refer to equations 1 through 3 for a formal description of the variables and model estimated. The model's
0.947 and standard errors used to obtain $t$-ratios were calculated using the Robust White procedure, using TSPTM v4.5.

\section{Results}

Calf weights were estimated as a function of age, sex, climate, calf weights at the previous weighing relative to an expected weight, and a 20-month compensatory gain as described in equation (1). Table 3 provides the parameter estimates and corresponding statistics for this model. Note that the model to estimate calf weights is constructed so that if climate and prior calf weights have been at their norms, weight is simply an $8^{\text {th }}$ order polynomial function of calf age in months with a constant weight percentage differential between steers and heifers. Figure 1 graphically describes this polynomial growth function for a steer calf from birth to 20 months of age as plotted against the actual calf weight data. Estimated calf weights from equation (1) are presented in Figure 2. Unlike logistical growth functions, the polynomial framework has flexibility to allow for the dip in calf weight that occurs from weaning and seasonal forage availability. An $8^{\text {th }}$ order polynomial was selected from polynomial orders of 3 to 10 that were estimated, applying the Schwarz (1978) criteria to calf weight estimated as only a function of calf age. On average, calf weights at the 12 -month weighing were $3.84 \mathrm{~kg}^{-1}$ head $^{-1}$ less than at the 8-month weighing. At any given age, heifer calves were estimated to weigh 2.25 $\mathrm{kg} \mathrm{head}^{-1}$ less than a steer calf. es are mid-range to those reported by Tronstad and Gum (1994). The calf crop is assumed to be a 50:50 mix of steers and heifers. For a $100-\mathrm{AU}$ ranch selling 159 or $204 \mathrm{~kg}$ calves, a total of 100 cows plus 20 heifers are exposed to the bull every year. The combined weight of heifer calves selected as replacements at weaning plus bred heifers will exceed the average weight of the 80-cow AUYs in the herd. But cows may die throughout the year and not just at weaning, offsetting the larger grazing needs of the combined heifer calf and bred heifer AUYs. Irrespective, the same heifer development costs are equally imputed for all scenarios. Out of the 100 cows, 16 are culled and 4 are expected to die. The $80 \%$ assumed fertility results in 96 calves born and the $2.5 \%$ calf death loss results in 93.6 calves at weaning. To replenish the cows that are culled or die, $42.7 \%$ (20/46.8) of all heifers are retained each year as replacements with $80 \%$ fertility. Thus, a $100-\mathrm{AU}$ ranch selling $159 \mathrm{~kg}$ or $204 \mathrm{~kg}$ calves would expect to sell 16.0 cows, 46.8 steer calves (i.e., $120 * 0.8 * 0.975 * 0.5$ ), and 26.8 heifer calves annually.

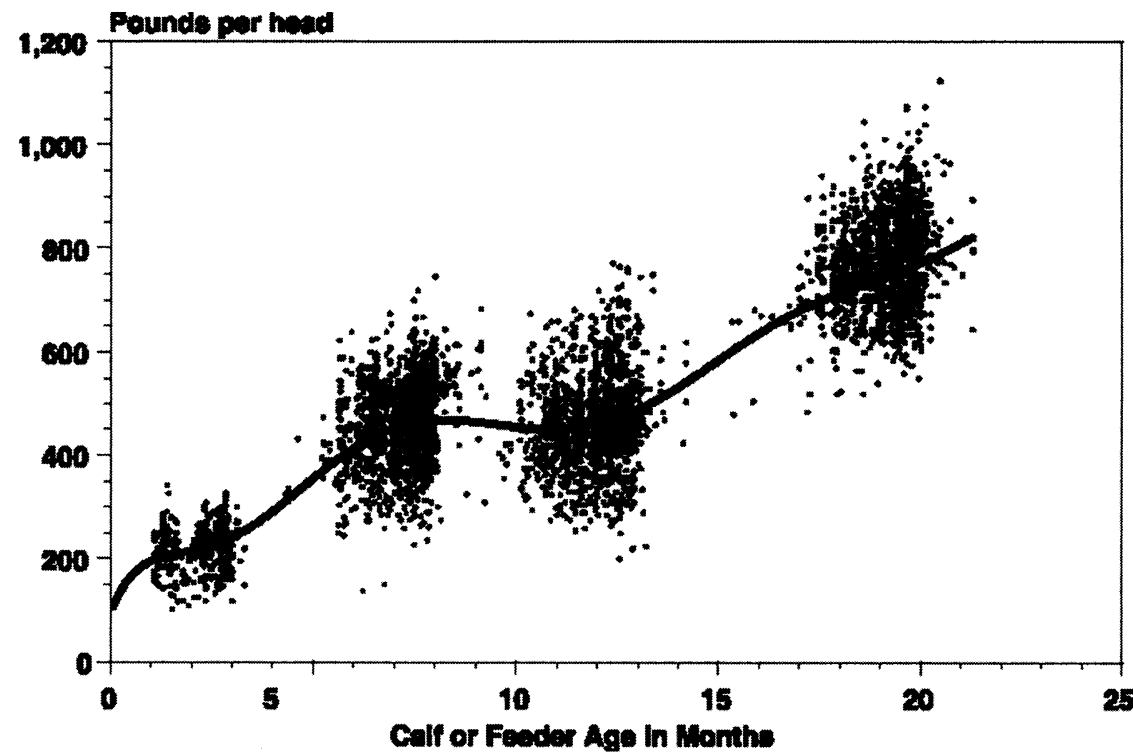

Fig. 1. Calf scale weights and estimated polynomial age growth function for steer calves. 


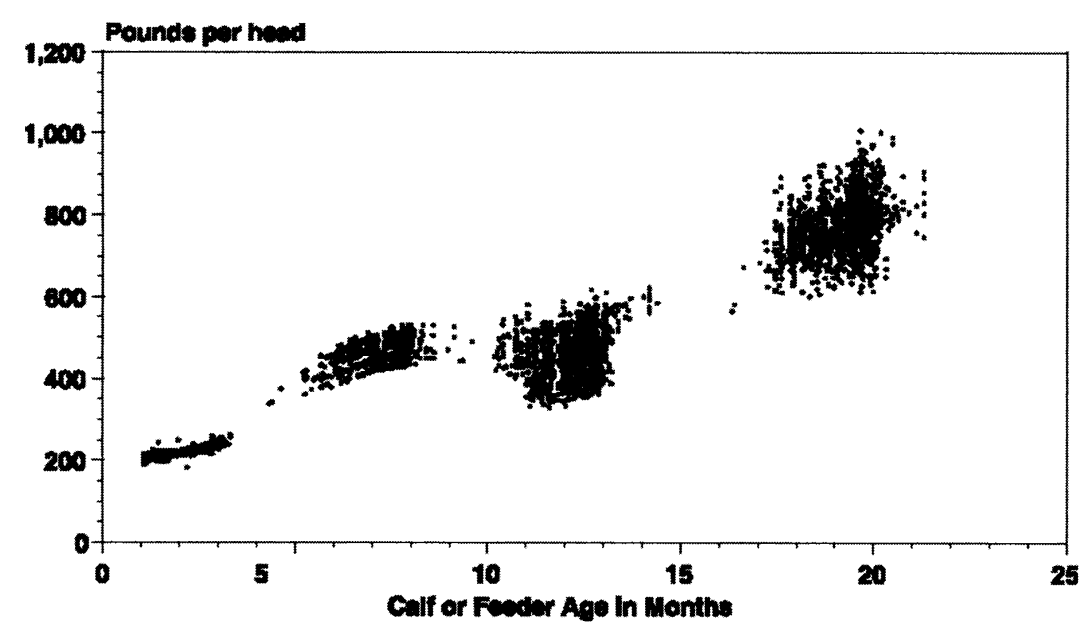

Fig. 2. Modeled calf weights based on equation 1.

If rainfall is above (below) the 30 -year average for the months prior to a weighing, calves would be expected to weigh more (less) than otherwise at their current weighing. Rainfall between the prior and current weighing is used as a proxy to estimate forage conditions being above or below their long-term average. As indicated by the estimated rainfall parameters (Table 3 ), if the accumulated rainfall between the 3-and 8-month weighings was above the 30-year average by $1 \mathrm{~cm}$, calves were estimated to weigh $2 \mathrm{~kg}$ head $^{-1}$ more at the 8-month weighing than if rainfall was equal to the 30 -year average. The magnitude and statistical significance of the rainfall variable decreases as the animal increases in age. This result is attributed to the 20-month compensatory gain effect and the greater importance of lagged weight components as the animal increases in age. That is, these factors were able to better capture both genetic and environmental components as the calves increased in age compared to the rainfall variable.

Using the weight gains estimated above, Cattle-Fax (1981-1998) prices for calf and cow sales, and the opportunity cost of forage described in Table 1 (i.e., reduced cow numbers for heavier calf weights), the average and standard deviation of 1999 real returns for different sale dates and weights is given in Table 4. A sale weight of $204 \mathrm{~kg} \mathrm{head}^{-1}$ for May with no supplemental feeding is the most profitable alternative for the southeast Arizona region. An average real return of $\$ 120.45$ AUY $^{-1}$ for the southeast was realized for the 19 years from 1980 to 1998 . The most profitable scenario for the central Arizona standard deviations associated with these weights are generally lower as well. The highest 2 weight classes of 295 and $340 \mathrm{~kg}$ head $^{-1}$ have a standard deviation that is on average $19 \%$ less than the more profitable lighter sale weights. However, the highest standard deviation of returns is also from feeding supplement and selling $340 \mathrm{~kg}$ head $^{-1}$ feeders in the southeast region during November. Feeding large quantities of supplement adds a cost that significantly decreases profitability when the price of heavy feeders is low. However, supplemental feeding can really boost revenues by bringing more calves and weight to market when prices for heavier feeders are strong in the fall. Combined cost and seasonal market forces make this production and marketing protocol the most risky.

While cull cow sales make up only $20 \%$ to $23 \%$ of total revenues, they account for the largest share of the profit differential between May and November sales. Of the $\$ 17.14$ profit difference between May and November sales for $204 \mathrm{~kg}$ calves from southeast Arizona not fed supplement, cull cow sales account for $52 \%$ of the favorable revenue difference between these months. Steer and heifer calf sales account for $33 \%$ and $15 \%$ of the favorable May sale revenue difference. For $250 \mathrm{~kg}$ sale weights from the central region feeding supplement, cull cow sales account for $46 \%$ of the favorable difference in May over November revenues, while steer and heifer sales account for only $37 \%$ and $17 \%$ of this difference. However, if cull cow weights for a ranch are less for May than November instead of being equal as

Table 4. Average 1999 real return and standard deviation ${ }^{a}$ of returns, (\$ AUY $\left.{ }^{-1}\right), 1980-98$.

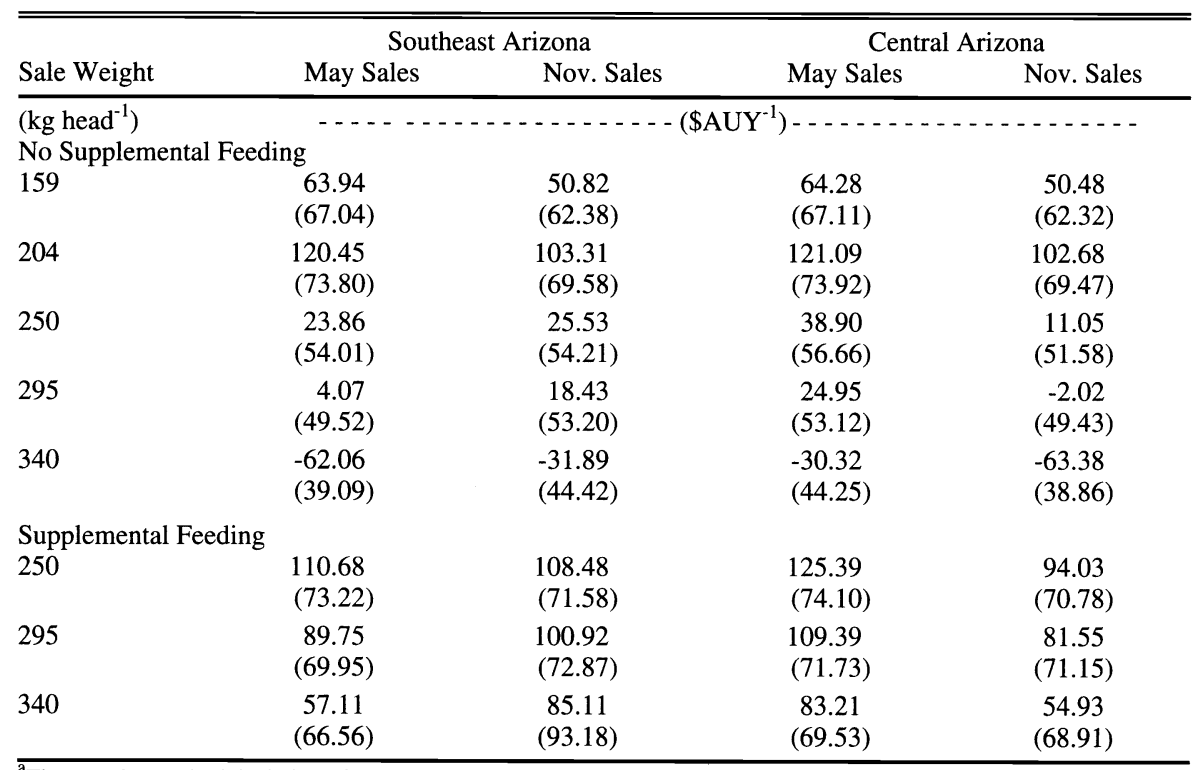

${ }^{\mathrm{a}}$ The sample standard deviation of returns is in parentheses below the average of annual real returns. 
Table 5. Average 1999 real return and standard deviation ${ }^{a}$ of returns $\left(\$ A U Y^{-1}\right)$ for extra grass year scenarios, 1980-98.

\begin{tabular}{lcccc}
\hline \hline & \multicolumn{2}{c}{ Southeast Arizona } & \multicolumn{2}{c}{ Central Arizona } \\
Sale Weight & May Sales & Nov. Sales & May Sales & Nov. Sales \\
\hline kg head $^{-1}$ ) & $-\ldots \ldots$ & & & \\
Supplemental Gains at No Supplement Cost & & & \\
250 & 131.57 & 118.82 & 135.85 & 114.72 \\
& $(73.41)$ & $(71.62)$ & $(74.21)$ & $(70.85)$ \\
295 & 121.15 & 121.63 & 130.33 & 112.65 \\
& $(70.29)$ & $(72.87)$ & $(71.96)$ & $(71.14)$ \\
340 & 99.04 & 130.58 & 114.68 & 96.49 \\
& $(67.06)$ & $(76.59)$ & $(69.92)$ & $(68.79)$ \\
Non-Supplemental Gains & with No AUY Reduction & & \\
250 & 164.39 & 147.21 & 165.39 & 146.26 \\
& $(79.48)$ & $(77.06)$ & $(79.67)$ & $(76.88)$ \\
295 & 199.26 & 190.50 & 200.63 & 189.18 \\
& $(84.65)$ & $(86.43)$ & $(84.91)$ & $(86.18)$ \\
340 & 237.49 & 235.73 & 239.28 & 233.99 \\
& $(92.88)$ & $(96.61)$ & $(93.21)$ & $(96.29)$ \\
\hline
\end{tabular}

${ }^{\mathrm{a}}$ The sample standard deviation of returns is in parentheses below average annual real returns. assumed, this would diminish the favorable revenue difference of May over November cull cow sales.

Without feeding supplement, the estimated polynomial age growth function is essentially flat after reaching 7 months of age or $204 \mathrm{~kg} \mathrm{head}^{-1}$ for the next 5.5 months. However, supplemental feeding is able to remove the long flat period for range calves from 7 to 12.5 months of age. Feeding supplement at the level described in Table 2 to attain the accompanying Average Daily Gains (ADGs) described in Table 1 increases average AUY ${ }^{-1}$ profitability for $250 \mathrm{~kg}$ calves sold in May by $\$ 86.82$ and $\$ 86.49$ for the southeast and central regions, respectively. Even though supplemental feeding is not always the most profitable option, it consistently increases the return for sale weights above $204 \mathrm{~kg} \mathrm{head}^{-1}$, anywhere from $\$ 83$ to $\$ 119$ $\mathrm{AUY}^{-1}$.

Table 5 illustrates what the return to difrancher had "extra grass" so that supplemental gains were obtainable without feeding supplement or no reduction in AUYs was charged for selling calves at heavier weights. These values are to provide an illustrative benchmark that can be used to interpolate an abundant forage situation rather than suggest that supplemental gains or no AUY reduction will be attained in an "extra grass" year. Even when supplemental gains are available at no extra feed cost, $250 \mathrm{~kg}^{-1}$ head $^{-1}$ sales are the most profitable except for November sales in the southeast region. In general, the opportunity cost associated with foregone calf numbers and lower prices does not outweigh the benefit of heavier calf ferent sale weights and dates would be if a weights, even when supplemental gains are imposed with no added feed cost. But if no AUY reduction is charged for producing heavier calves, the heaviest calf weight of $340 \mathrm{~kg} \mathrm{head}^{-1}$ yields the highest return with May sales still somewhat preferred over November sales for both regions.

While supplemental feeding removes the long flat growth period for range calves, it may also have an impact on fertility of the herd. The value (\$AUY ${ }^{-1}$ ) of a $1 \%$ increase in fertility associated with feeding supplement is given in Table 6 , utilizing the supplemental ADGs described in Table 1 . The value of a $1 \%$ increase in fertility is about $\$ 5.50 \mathrm{AUY}^{-1}$ for all supplemental fed sales. Using the returns given in Table 4 , it would take an increase in fertility from feeding supplement of more than $1.78 \%$ ((120.45$110.68) / 5.49$ ) before it would be more profitable to sell calves at 250 rather than $204 \mathrm{~kg} \mathrm{head}^{-1}$ for May sales in southeast Arizona. Because supplemental feeding and May sales of $250 \mathrm{~kg} \mathrm{head}^{-1}$ is the most profitable option for the central Arizona region, fertility would have to decline by $-0.78 \%$ ((121.09-125.39)/5.53) before it would not pay to feed supplement and increase the May sale weight from 204 to $250 \mathrm{~kg} \mathrm{head}^{-1}$. The value of a $1 \%$ increase in fertility accompanied with supplemental feeding is about the same for all sale weight categories because the supplemental fed rates of gain described in Table 1 are roughly the same for all calves above 204 $\mathrm{kg} \mathrm{head}^{-1}$.

\section{Discussion and Conclusions}

This study shows that the benefit of higher sale weights was not enough to overcome lower calf prices and fewer calf and cull cow sales for calf weights above $204 \mathrm{~kg} \mathrm{head}^{-1}$ without feeding supplement. Supplemental feeding removes the nearly 0 rate of gain for calves from 7 to 12.5 months of age, so that for the central Arizona region $250 \mathrm{~kg}^{\text {head }}{ }^{-1}$ calf sales in May fed supplement is the most profitable option. May sales were found to be more profitable than November sales, even with lower ADG rates. More favorable market conditions for May than November sales are the main reason why May sales were often more profitable than November sales.

In calculating cost and return estimates for cow-calf ranches in Arizona, Teegerstrom and Tronstad (2000) conducted focus groups in 5 different regions to gain insights into typical production practices. They reported a typical sale weight for steers of between 204 to $250 \mathrm{~kg}$ head $^{-1}$, depending on the ranching region. This result is consistent with the most profitable sale weight category of $204 \mathrm{~kg}$ head $^{-1}$ for the southeast and $250 \mathrm{~kg}$ head $^{-1}$ for the central Arizona regions. With regards to sale date, a fair number of ranchers market their calves in the fall rather than the spring, and May was determined as the most profitable sale time for both regions. Given that the difference in profitability between May and November
Table 6. Value of a 1\% increase in fertility ${ }^{\mathrm{a}}$ associated with supplemental feeding.

\begin{tabular}{|c|c|c|c|c|}
\hline \multirow{2}{*}{ Sale Weight Categor } & \multicolumn{2}{|c|}{ Southeast Region } & \multicolumn{2}{|c|}{ Region Central Region } \\
\hline & Mid-May & Mid-Nov. & Mid-May & Mid-Nov. \\
\hline$\left(\mathrm{kg} \mathrm{head}^{-1}\right)$ & ------.. & -1-- & 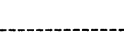 & ---- \\
\hline 250 & $\$ 5.49$ & $\$ 5.40$ & $\$ 5.53$ & $\$ 5.36$ \\
\hline 295 & $\$ 5.52$ & $\$ 5.60$ & $\$ 5.62$ & $\$ 5.51$ \\
\hline 340 & $\$ 5.40$ & $\$ 5.46$ & $\$ 5.59$ & $\$ 5.46$ \\
\hline
\end{tabular}

${ }^{\mathrm{a}}$ For fertility changes up to $85.5 \%$ after the increase and starting with an initial fertility rate above $34.2 \%$. Given a 100 AUY ranch with fertility rates above $85.5 \%$, bred cows will need to be sold or less than 20 heifer calves will need to be retained for breeding to keep the herd at a constant AUY. Fertility rates below 34.2\% are unable to sustain the cow herd even with $100 \%$ of the heifer calves retained for breeding. Value of fertility utilizes the ADGs associated with feeding supplement as described in Table 1. 
sales was found to be relatively small in comparison to alternative sale weights, small differences in biological productivity from what was assumed in this analysis could shift results to favor November sales, especially for the southeast Arizona region. In addition, rates of gain were adjusted from a calculated weight gain using expert opinion for fall and winter calving dates and changes in the values assumed could sway results. This indicates that formal studies on these relationships should be considered. High labor and distribution costs to remote and difficulty in accessing range sites could also make supplemental feeding less attractive than what we have determined in our analysis. However, each rancher can adjust the return values presented to fit their own cost and production values in evaluating alternative sale dates and weights.

It is also important to note that a more flexible sale date, weight combination, and supplemental feeding strategy could have generated more net return than the "fixed strategies" above. For example, a strategy that can take advantage of market opportunities for feeding calves to a heavier weight when corn prices are high and forage is available would outperform the best "fixed strategies" presented of always producing 204 or $250 \mathrm{~kg}$ calves for sale in May. That is, when corn prices are so high that heavier calves sell for a higher price $\mathrm{kg}^{-1}$ than light calves, a rancher benefits from both the higher price received and more kgs sold by keeping calves until they are at a heavier weight class.

\section{Literature Cited}

Cattle-Fax. 1981-1998. Cattle-fax feeder cattle cash prices for Arizona.

Clayton, H.L., R.P. Morris, and J.R. Wight. 1983. Using precipitation to predict range herbage production in Southwestern Idaho. J Range Manage. 36:766-770.

Fox, D.G. and J.R. Black. 1977. A system for predicting performance of growing and finishing cattle. 1. Development of a model to describe energy and protein requirements and feed values. Feedstuffs 49:21-22, 27.

Gao, X. 1996. An evaluation of hedging strategies for alternative sale dates and weights. M.S. Thesis, Univ. Arizona, Tucson, Ariz.

Lambert, D.K. 1989. Calf retention and production decisions over time. W. J. Agr. Econ. 14:9-19.

Mayes, H.M. and T.F. Archer. 1982. Arizona cattle ranches on public land. Univ. Arizona, College of Agr. Range Task Force Rep. Tucson, Ariz.

Schwarz, G. 1978. Estimating the dimension of a model. Ann. Statist. 6:461-464.

Sprinkle, J.E. 2000. Managing nutritional challenges to reproduction. Univ. of Arizona Coop. Exten. Publ. AZ1166, Tucson, Ariz.

Teegerstrom, T. and R. Tronstad. 2000. Cost and return estimates for cow/calf ranches in five regions of Arizona. Univ. of Arizona Coop. Exten. Publ. AZ1193, Tucson, Ariz.

Tess, M.W. and B.W. Kolstad. 2000 Simulation of cow-calf production systems in a range environment: I. Model Evaluation. J. Anim. Sci. 78:1170-1180.
Tronstad, R. and R. Gum. 1994. Cow culling decisions adapted for management with CART. Amer. J. Agr. Econ. 76:237-249.

Tronstad, R., T. Teegerstrom, and X. Gao. 2001. Trade-off between cow numbers, calf size, and sale date incorporating seasonal factors and supplemental feeding: Ranch Business Management. pp. 181-187 In: Tronstad, R., J. Sprinkle, and G. Ruyle (ed.), Arizona Ranchers' Management Guide. Univ. of Arizona Coop. Exten. Publ. AZ1279, Tucson, Ariz.

TSP 1999. User Manual Version 4.5 TSP International, Palo Alto, Calif .

U.S. Department of Agriculture. 1980-1998. Agricultural Prices. National Agr. Stat. Serv., Agr. Stat. Board, Washington D.C., recent data available at http://usda. mannlib.cornell.edu/reports/nassr/price/pap-bb/ (last accessed August 2002)..

U.S. Department of Agriculture. 1982-1998. Cow-calf production cash costs and returns. Econ. Research Serv., Washington D.C., recent data available at http://www.ers.usda.gov/Data/CostsAnd Returns/testpick.htm (last accessed August 2002).

Van Tassell, L.W., R.K. Heitschmidt, and R.J. Conner. 1987. Modeling variation in range calf growth under conditions of environmental uncertainty. J. Range Manage. 40:310-314.

Western Regional Climate Center. 1961-1998. Monthly total precipitation for San Carlos reservoir, Arizona, available at http://www.wrcc.dri.edu/summary/climsmaz.html (last accessed August 2002). 